\title{
РЕЗУЛЬТАТЫ ВНЕДРЕНИЯ ИНТЕГРИРОВАННОЙ ПРОГРАММЫ «НОРМА» ДЛЯ ПАЦИЕНТОВ С САХАРНЫМ ДИАБЕТОМ 1 ТИПА
}

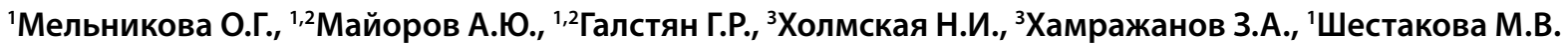 \\ 'ФГБУ «НМИЦ эндокринологии» Минздрава России, Москва \\ ${ }^{2}$ ОООИ «Российская Диабетическая Ассоциация», Москва \\ ${ }^{3}$ Вологодский региональный диабетологический чентр, Вологда
}

ЦЕЛЬ: оценить влияние программы «Норма», представляющей собой совокупность мероприятий, процессов, устройств, а также цифровых и коммуникационных решений, направленных на развитие навыков самостоятельного управления для пациентов с сахарным диабетом (СД) 1 типа.

МАТЕРИАЛЫ И МЕТОДЫ: проведен ретроспективный анализ данных пациентов, которые приняли участие в программе «Норма» в период с 01.01.2020 по 31.10.2020 в Вологодском региональном диабетологическом центре. Программа разработана экспертами ФГБУ «НМИЦ эндокринологии» Минздрава России и ОООИ «Российская Диабетическая Ассоциация» при поддержке фармацевтической компании «Санофи». Программа включает в себя четыре компонента: обучение, устройства гликемического контроля, административную и медицинскую поддержку. Компонент «Обучение» создан по аналогии со структурированными программами «Школ для пациентов с сахарным диабетом» и реализован в мобильном приложении для смартфона, которое дает возможность проходить последовательно 30 обучающих модулей. Все модули имеют текстовые файлы с подробным описанием обсуждаемых вопросов, видеоролики в формате вопрос-ответ с коротким комментарием эксперта и тестовые задания, для проверки усвоения и закрепления материала. Компонент «Устройства гликемического контроля» в программе был представлен глюкометром с автоматической передачей данных в мобильное приложение для смартфона. Компонент «Административная поддержка» был представлен куратором без медицинского образования, формирующим группы, оказывающим помощь в работе с приложениями, включая выгрузку отчетов для врача, контроль за прохождением образовательного курса. Компонент «Медицинская поддержка» был представлен рутинными визитами к эндокринологу по месту жительства. Через 3 и 6 мес после начала участия в программе были проанализированы динамика показателей гликемического контроля ( $\left.\mathrm{Hb}_{1 c}\right)$, дозы инсулина, уровень знаний о СД по опроснику из 20 вопросов.

РЕзУЛЬТАТЫ: проанализированы данные 69 пациентов с СД 1 типа, из них 69,6\% женщин. Средний возраст участников составил $35,9 \pm 10,7$ года. На момент вступления в программу исходный средний уро-

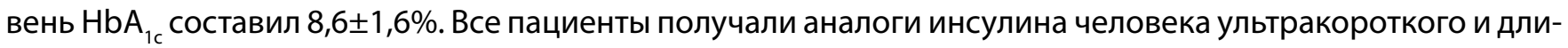

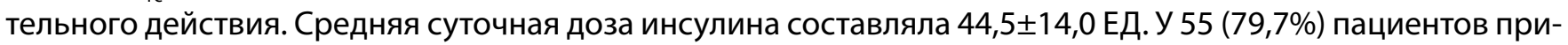
сутствовали осложнения СД. При анализе данных было отмечено, что среднесуточные дозы инсулина

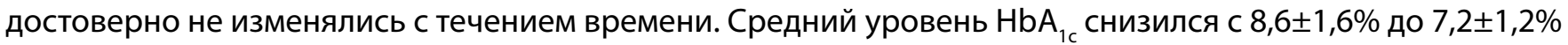
$(p<0,05)$ и 7,5 $\pm 1,7 \%(p<0,05)$ через 3 и 6 мес соответственно. Через 3 мес участия в программе уровня $\mathrm{HbA}_{1 c}<7,0 \%$ удалось достичь у 48,5\%, через 6 мес - у 51,2\% пациентов; индивидуальных целевых уровней $\mathrm{HbA}_{1 с}$ через 3 и 6 мес наблюдения достигли 38,2\% и 34,2\% пациентов соответственно. Средний уровень

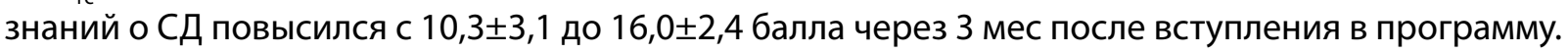

ВЫвОды:у пациентов с СД 1 типа, принявших участие в программе «Норма», наблюдалось улучшение показателей гликемического контроля через 3 и 6 мес, без увеличения средней суточной дозы инсулина, а также повышение уровня знаний о СД. 